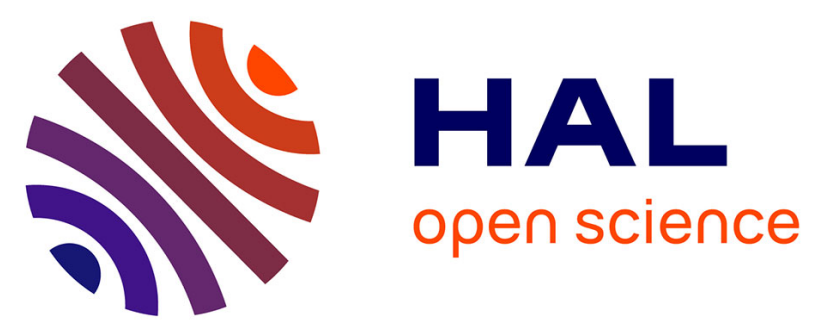

\title{
Mars-105 study: Time-courses and relationships between coping, defense mechanisms, emotions and depression
}

Michel Nicolas, Gro Mjeldheim Sandal, Karine Weiss, Anna Yusupova

\section{To cite this version:}

Michel Nicolas, Gro Mjeldheim Sandal, Karine Weiss, Anna Yusupova. Mars-105 study: Timecourses and relationships between coping, defense mechanisms, emotions and depression. Journal of Environmental Psychology, 2013, 35, pp.52-58. 10.1016/j.jenvp.2013.05.001 . hal-01730516

\author{
HAL Id: hal-01730516 \\ https://hal.science/hal-01730516
}

Submitted on 14 Mar 2018

HAL is a multi-disciplinary open access archive for the deposit and dissemination of scientific research documents, whether they are published or not. The documents may come from teaching and research institutions in France or abroad, or from public or private research centers.
L'archive ouverte pluridisciplinaire HAL, est destinée au dépôt et à la diffusion de documents scientifiques de niveau recherche, publiés ou non, émanant des établissements d'enseignement et de recherche français ou étrangers, des laboratoires publics ou privés.

\section{(1) (1) $\$$}

Distributed under a Creative Commons Attribution - NonCommercial - NoDerivatives $\mid 4.0$ 


\title{
Mars-105 study: Time-courses and relationships between coping, defense mechanisms, emotions and depression
}

\author{
Michel Nicolas ${ }^{a_{2} *}$, Gro Mjelđheim Sandal ${ }^{\mathrm{b}}$, Karine Weiss ${ }^{c}$, Anna Yustpova ${ }^{\mathrm{d}}$

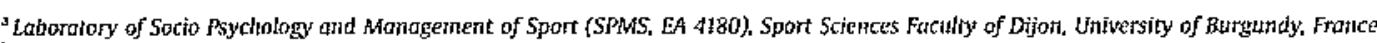 \\ "Department of Psychosocial Science, Gnversily of Berget. Normay \\ 'Laboratory of Social Pyycholusy (LPS, EA 849), Univertily of Phmes, Pronce

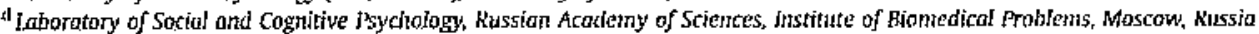

Reywords:
Coping
Defense
Emotions
Depression
ICE tuvironnents
Adapation

\begin{abstract}
A B $5 \mathrm{~T} R \mathrm{~A} C \mathrm{~T}$
This study intestigated the time-courses and the relationships berween coping, defense mechanisns, emotions and depression considered ạs key factors th adaptation to lCË: (Isolated and Confined Extrene) environments. During the space simulation, the Mars-105 experiment. positive emotion decreased significantly and significant positive correlations were found betwcen mature de lenses and boch positive emotions and Task-Oriented Coping (TOC), as well as between Disengagement-Oriented Coping (DOC) and symptoms of depression. These findings show the impact of space simulation on affetive states and the retations of defeslse to both coping and emotion, which underline the rote of these psychological conitructs involved in psychologicat adaptation processes. The results of the present study add insights into the effects of space sirfulation in order to offet the participants a better selection, preparation and follow-up of these psychological components recognized as essential for adaptation to extreme envifonments.
\end{abstract}

\section{Introduction}

It has been clearly tecognized that psychological and psychosocial factors significantly modify human behaviors and performance during real space fliglyts (Bishop, 2004; Manzey k Lorenz. 1997). Adaptation mechanisns to such an isolated and confined extreme (ICE) environment have become an issue of major importance (Kanas, 1997). Currently, this issue is also one of the main concelns for long space missions such as the Mars expedition project. The effect of long-term isolation and cosfinement on healthy volunteers can be addressed via ground-based simulations (Manzey, 2004; Nicolas \& Weiss, 2009; Sandal, Leon, \& Palinkas, 2006). The Mars-105 experiment is a space simulation study designed to investigate the effects of an ICE environment on most of the individual and social psychological outcomes and to prepare the next 520-day mission. Specifically, this paper focuses on time patterns and relacionships between coping strategies, deferse mechanisms and mood.

- Corresponding atthor. Faculté des sciences du Sport, UFR STAPS, Universilé de Bourgegnc, BP 27877, 21078 Dupon Cedex, France. Tel.: +333803990 11: fax: +333 80396702.

E-mail address: michel.nicolas@u-bo乡 rgogne.Fr (M. Nìcolas).
During profonged space missions, the most important stress factors could include microgravity, monotony and boredom resulting from low workJoad and hypostimulation, lack of com [ort, confinensent and isolation involving timited social relationships such as the separation from family and friends (Manzey. 2004: Suedfeld, 2005). The adaptation of crewtuembers to these living conditions clearly shows a number of psychological factors inctuding individual experiences, personality, leisure activities, and psychological adaptation mechanisms (e.g. copinc strategies, defense mechanisns and emotions) used to deal with such stressors (Palinkas, 2003; Willians \& Davis, 2005). Behavioral and affective reactions to these stressors can include a variety of symptoms inctuding an increase it! siress level, emotional instability. hypersensitivity or depressive reactions (Grigoriev, Kozereako, \& Myasnitov, 1987; Kanas, 1991). The capacity of astronauts and space fiyers to cope effectively with these various stressors is a major part of the success of manned space missions (Kanas \& Manzey, 2008).

Because of theoretical advancements, it has been recogrized that the two major concepts involved in psychological adaptation to constraining situations are coping strategies and defense mechanisms (Cramer, 1998; Parker Encler, 1996). DM are considered as being more oriented toward inner conflicts and dispositions and part of the individual's cnduring personality. Whereas CS are 
considered to be positively oriented toward adaprafion to reality and determined by situdion-specific variables (Nicolas \& Jebrane, 2008a: Parker \& Endler, 1996). However, recent empirical studies among the general population showed that CS and DM are both involved and conttibute to the adjustment process in a complementary way in recovery after surgical interventions (Fulde, ] lunge, \& Alrens, 1995), in adjustment with adolescents (Erickson, Feldman, \& Steiner, 1997), or in marital adjustment (Bouchard \& Therrault, 2003). These results were reproduced in high-level sport competition, underlining that the simultaneous investigation of coping strategies and defense mechanisms may improve understanding of the complex and dynamic ways in which people deal with the demands of constraining situations (Nicolas \& Jebrane, 2008b). Despite the meaningftal value of these studies, very little if any research on DM or on the link between CS and DM in outer space situations or in other extreme situations exists.

Results concerning the variations. in CS or enotion in ICE environments show inconsistencies probably due to the specificity of the situations and the participants' characteristics. Previous studies reported that coping strategies are likely to increase as time passes in ICE environments, sucli as a lyperbaric chanber (Palinkas et al. 1989: Sandal, Bergan, Warnclue, Værnes, \& Ursin, 1996). This was interpreted as a trend for reducing apprehension of the potential risks (Radloff \& Helmretch, 1968; Suedfeld \& Steel, 2000). However. in the Antarctic environjent, a comparison between the CS used before and at the end of the expedition showed a decrease in seeking social support and in problen-focused coping, indicating. a less freguent use of these coping strategies (Peri, Scatata, \& Barbarito, 2000). The authors suggested that the expedition mermbers probably tended to protect themselves from the frustration and emotional deprivation that often characterizes the situation in Antarctica.

In space flights, a quantitative sturdy based on content analysis reported that astronauts used problem-oriented rather than emotion-oriented coping strategies with a predominamce of Seeking Social Support Problems before Planful Solvilug Problems and Endurance/Obedience/Effort Problews, indicating the importance of mutual reliance and cooperation within space crews, as well as supportive conversations with family members (Suedfeld, Brcic, \& Legkaia, 2009). Furthermore, coping strategies indicated changes across space flight stages (Pre-, It- and Postflight). Two problem-orierted strategies showed significant changes during the figltt. Confrontation and Escape/Avoidance werc at their lowest level ouring the in-flight stage compared to the pre and post-fliglt stages. These phase-related changes in inflight were maisly explained by the imporance of emorionally calm interactions among the crew of the space capsule, and for the pre and post-flight stages by the fart that physical escape in space is impossible, except for scheduled or emergency EVAs. White one of the emotion-oriented coping strategies (Denial) showed an opposire pattern with a peak during the in-flight phase, this maty have been a stbstitute for orlyer less acceptable strategies during flight such as Confrontation (Suedfeld et al., 2009).

Research on the time-course of emotional states during space flights has shown the absence of time effects that may be related to the support of space psychologists in mission control who use a variety of countermeasures such as communication with family and friends on the ground via audiovisual links or e-mails, and gifts or Ietters sent up from honte during resupply missions (Kands et al. 2005). These activities may have helped to lower the effects of periods of monotony and homesickness on orbit. However, another study showed the developrient of negative emotions during the first month of space flight which is accompanied by adaptation to microgravity, After six weeks, boredom, depression, anxiety. irritability and fatigue provoke increases in operator's" mistakes (Gushin, 1995). Since the 1960s, the first anecdotal reports in Antarctic mentioned that minor emotional disturbances were very common but pathological cases were extremely rase (Gunderson, 1963). Research conducted among over-winterers for several years suggests that potertial candidates for long-duration missions in the Antarctic should demonstrate emotional stability (e.g-, Gunderson, 1974; Palinkas, Gunderson, Holland, Miller, \& Jolinson, 2000; Palintas \& Suedfeld, 2007; Steel, Suedfeld, Peri, \& Palinkas. 1997).

ICE envitonments such as austral winter in Antarctica have long been associated with increases in depression, insomnia, hostilicy. anxiety, and the use of alcohol (Palinkas \& Browner; 1995; Wood, Lugg, Hysong. \& Harm, 1999). Among the impaired psychological effects obscrved during space analog such as head down tilt longterm bed rest, depression was also shown to increase (1shizaki et al., 1994, 2002; Styf, Hutchinson, Carlsson, \& Hargens, 2001). After the midpoint of Russian space missions, symptoms of depression were reported during the second pait (Myasnikov \& Zalnaletdinov, 1998). Shutcle/Mir and ISS data indicated reports of symptoms of depression during both American and Russian space nissions although the Jevel was tarely pathological (Kanas \& Manzey, 2008).

However, these results observed during wintering. polat expeditions, 5 pace analog environments or orbital space fights should evolve in a different way during long-term interplanetaly voyages. These missions have specificities such as the length of the mission (at least two years), comntuication delays, greater crew autonomy. a severe sense of isolation and separation from the Eartl with the so-cailed "Earth-out-of-view phenomenon", infrequency or impossibiliry of receiving stopplies, the impossibility of evacuation for a medical or psycliatlic emergency, the stronger impact of habitability and harsj living conditions in a space habitat with a lack of privacy and personal space that is more likely to become essential in sucti settings, the restricted range of environmental cues, the specific workload imposed on the astronatats, complex psychosocial issues tue to the monotony of social contacts with the sane crewmenbers, the lengthy separation from the usual social network of family and friends, and other environmental bazards such as microgravity, exposture to high doses of radiation and potential collisions with micrometeorites (Kanas, 2011; Kanas \& Manzey, 2008; Manzey, 2004: Patinkas, 2001; Sandal et al., 2006; Suedfeld, 1991).

Thus, more empirical work is needed to define the mechanisms and processes (e.s. coping straregies, defense mechanisms and entional srabiliry) that promoce optimum adaptation to these specifics challenges during long-duration space missions (Kanas, 201t; Palinkas, 200t; Sandal et al., 1996; Suedfeld \& Steet, 2000) Given the previous results in the literature, we supposed that a confined and isolated situation of 105 days would involve changes and relationships between coping, defense mechanisms, amotions and depression.

\section{Methods}

All volunteers underwent a thorough clinical examination, both medical and psychological, and received verbal and written explanations about the study objectives, procedures and potential risks of the experiment before participating in the Mars-105 campaign sponsored by the European (ESA) and Russian Space Agencies (Roscosmos). The participants gave their written informed consent to participate in this experiment. The study was approved by the ethics committee of the European Space Agency and the Institutional Review Board of the Institute for Bio-medical Problems (JBMP). 


\section{2,I. Participants}

The crew consisted of six men ranging in age fion 25 to 40 $(32.7 \pm 5.9$ years, mean \pm SD) representing different European nationalities, four Russians and two Europeans (German and French). For European candidates, the setection process started with some 5600 applicants. Four candidates were finally selected. From these four candidates, two were assigned as prime crewmember and the two others were acted as their backup, to replace a prime crewmember until the last moment if necessary. The selection was based on educational, professional, medical and psychological criteria similar to those required for potential space flyers.

\subsection{Procedure}

The Mars-105 campaign was designed to investigate the sorfal and individual psycloological conditions in long-term missions such as a space mission to Mars. Mars-105 was a ground-based space simulation reproducing with higher fidelity the conditions of an actual space flight apart from the microgravity. The conditions refiect the 3 main characteristics of a space simulation: (1) envijonmental conditions that simulare an artificial atmosphere at normal barometric pressure; (2) the relevant operational activities (e.g. timeline, organization, occupacion, autonomy), and (3) paticipant characteristics similar ro actual space fyers (e.g., demographics, mtilticujetral, personality).

This experiment was a 105-day ICE environment study conducted at the Instifute for Bio-Medical Problems (IBMP) in Moscow with the participation of the European Space Agency (ESA) and the Russian Space Agency (Roscosmos). The current study was a tongitudinal single-group design with repeated meastres across 12 assessments during 3 periods (baseline, ICE period, and postisolation) over a 4 -month period.

Psychological measures were assessed at baseline -14, $7,-3$ days before lCE period (BDC 1, BDC 2, BDC 3), at 1, 23, 44, 65, 86 and 99 days for the ICE period (ICE 1, ICE 2, ICE 3, ICE 4, ICE 5 and ICE 6), and in post-ICE period at $+1,+3$ and +7 days after the ICE period (Post 1, Post 2, Post 3). Prior to the confinenent period, the procedures and administration of the self-evaluation questionnaires were clearly explained to all the participants by the first author during pre isolation under the same conditions (personal computer in an individual room in the habitat module) and measures were taken to ensure that the participants understood the project requirements and the items on the questionnaires. The other questionnaires were administered and collected on the personal computer located in each individua! roon.

\subsection{Facilities}

The Mars-105 isolation facility was located at the IBMP site in Moscow. The layout of the isolation facility comprised four hermetically sealed interconnected habitat modules (principal living quarters, medical, storage ard Mars landing simulator modutes). pius one external module, which was used to simulate the 'Martian surface'. The total volume of the habitat modules was $550 \mathrm{~m}^{3}$.

The principal fiving quarters, which was the matio living quarters (3.6 $\times 20 \mathrm{~m}$ ), inciuded a kitchen-dining room, a living room, the main control room, a toilet and six individual rooms $\left(2.8-3.2 \mathrm{~m}^{2}\right)$ with a bed, a desk with a personal computer, a chair and shelves for personal bolongings. The medicat motule $(3.2 \times 11.9 \mathrm{~m})$ was designed for routine medical and telemedical examinations, a laboratory. diagnostic investigations and isolation of an ill crewmember if necessary. The storage module $(3.9 \times 24 \mathrm{~m})$ housed a food storage room, an experinzental greenhouse, a bathroom (without water), a sauna and a gym. The crew stayed in these modules under conditions of altificial atmospleric environment at nor'mal barometric pressure.

\subsection{Instituments}

\subsubsection{Coping}

Coping was assessed with the sltort version of the COPE scale which was designed to assess the ways people respond to stress (Carver, 1997). Participants were instructed to indicate the extent to which each item represented how they tried to deal with stress during the experiment over the past three days. The 28 items were rated on a 7-point likert-type scale ranging from 0 (never) to 6 (always). On the basis o[ a hierarchical organization of the coping construct (Skinner, Edge, Altman, \& Sherwood, 2003), coping strategies were grouped into two second-order dimensions of coping: task-oriented coping (TOC, active coping, planning, and positive reappraisal) and disengagement-oriented coping (DOC. behavioral disengagement, self-blane, and denial). The intemal consistency of the coping dimensions was examined using Cronbach's alpha coefficient and was acceptable: task-oriented coping $(a=0.81)$ and disengagement-oriented coping $(\alpha=0.73)$.

\subsection{Depression}

The Beck Depression Inventory-ll (BDI-II; Beck, Steer, \& Brown. 1996 ) is the most widely. used questionnaire for assessing severity of depression in psychiatric and normal poputations in both clinica! and research settings. This questionnaire is a 21 -item self-report measure evaluating depressive symptom (e.g., sadness, crying indecisiveness). The response format is from 0 to 3 to reflect the intensity of the sympton corresponding to the diagnostic criteria for deptessive disorder as defined by the Diagntostic antd Staristical Manuat of Mental Disorders (DSM-IV; American Psychiatric Association, 1994). The following ottoff scores and interpretive labels correspond to scores on the BDI-II: minimal (013), mild (14-19), moderate (20-28), and severe (29-63) depression. The psychometric properties of the BDI have been well documented and received strong support (Steer, Rissmiller, \& Beck, 2000). The internat consistency was deemed acceptable with a score of 0.82 .

\subsubsection{Emotions}

The Positive Affect Negative Affect Schedule (PANAS, Watson, Clatk, Tellegen, 1988) is a valid and retiable measure of affective states bategorized into lighel-order dimensions of affective experience called positive and negative affect (Watson et al. 1988). This setf-report adjective cliecklist consists of two 10 -item subscales designed to measure positive (i.e., acrive, alert, attentive, determined, enthusiastic, excired, inspired, interested, proud, and strong) and negative affect (t,e, afraid, ashamed, distressed, guilty, hostile, irritated, jittery, nervous, scared, and upset) experienced during a given time frame.

In the present study, we instructed the participants to rate the extent to which chey experienced each affective state during the previous three days. Individuals responded to each iten on the following scale: (1) very slightly or not at all. (2) a little. (3) moderately, (4) quite a bit and (5) extremely. Positive affect represents the "extent to which indjviduals feel enthusiastic, active, and alert" (Watson et al. 1988), A high score on the positive affect scale denotes an optimal state of energy, concentration, and pleasurable engagement whereas a low score reflects sadness and lethargy. Negative affect represents a general dimension of subjective distress subsuming a variery of states such as anger and anxiety. $A$ high score on the negative affect scale indicates distress and unpleasant engagement whereas a low score denotes calmness 
and serenity. Its adequate psychometric properties bave contributed to the widespread use of the PANAS (Watson et al., 1988; Watson \& Clark, 1997). Jn the present study, Cronbach's alphas were 0.84 for the positive affects, and 0.78 for the negative affects.

\subsection{Defense mechanisms}

The Defense 5tyle Questionnaire assesses an individual's conscious derivatives of defense mechanisms (DSQ Andrews, Singh, Bond, 1993). The respondent is asked to indicate the extent to which each statement corresponds to his or her perception using a Likert-type scale going from 0 (strongly disagree) to 5 (strongly agree), The DSQ-60 is a 60-item version with three bigherorder factors: Mature, i.e., the tendency to use problem-solving bebaviors; Intemediate, i.e., the tendency to manifest altruistic and prosocial behaviors or attitudes; and lmmature, i.e. the tendency to express affect through reactions of withdrawal or acting out. The DSQ-60 was validated for adequate psychometric properties (Bonsack, Despland, \& Spagnoli, 1998).. In the present study. alpha coeffetents were 0.77 for the Mature factor, 0.75 for the lnternediate factor and 0.72 for the Immature factor.

\subsection{Statistical analyses}

Inherent to this type of experinzental condition, the sample size was small (6 participants). Consequently, the data were anafyzeơ using non-parametric statistics. Changes in psychological states were assessed first using Friedman's test. which is a non-parametric, one-way, repeated-measures analysis of variance by ranks. If differences were detected, the Wilcoxon signed-ranik paired t-test was applied in an attempt to detertrine which specific values were significantly different. The level of significance for these anaiyses was corrected using Bonferroni-type adjustment in order to maintain the Type-1 error probability at the 0.05 alpha level. In addition, correlations were made using the Spearman rank correlation coefficient $\left(r_{s}\right)$ between the mean scores of psychological variables. All values in the text are presented as means and standard deviations. Means and standard deviations of the dependent variables botll for each patticipant and the groug are reported in Table 1.

\section{Results}

The Mars-105 experiment was conducted successfully. Alt the participants completed the ICE period with no major medical problems or psychological disorers, and completed an average of more than $93 \%$ of the scheduled questionnaires. No subject completed less than $89 \%$ of his sessions.

3.1. Time-course in coping emotion, defense mechanisms and depression over time

The effect of isolation and confrnement in this 105-thy groundbased simulation on mechanisms involved in the psychological adaptation process reported few changes in the following psychological variables: coping, enotion, defense mechanisms and depression.

hmong the several psychologicat variables assessed, only emotion measured with the PANAS indicared changes throughour the expertiment. Positive emotion decreased progressively ( $F$-test ${ }_{t}$ Chi $2-22.81, p<0.02$, see Fig. 1 ) duting the 105-day experiment for all the participants, whereas changes in negative enotion were not significant (F-rest, Chi2 $-15.53, p \rightleftharpoons 0.16$ ), nor were changes in coping strategies (Task-Oriented Coping (TOC) and DisengagementOriented Coping (DOC) (respectively F-test, Chi2 - 0.26, $p=0.87$ and F-test, Chi2 $\because 4,33, p=0.11$ )), defense mechanisms (Mature Farror (F-test, Cli2 $=7.87, p-0.34$ ), Internediate Factor ( $F$-test. Chi2 $-3.75, p-0.81$ ), Immature Factor (F-test, Chi2 - 3.67. $p=0.82)$ ), and depression level (F-test, Chi2 $-4.73, p=0.69$ ).

\subsection{Relations berween coping, entotion, defense mechanisms and depression}

Correlational analyses showed relationships between coping. emotion, defense mechanissns and depression. Coping strategies were related to defense mechanisms, emotions, and depression. Throughout the experiment, the mean of TOC was positively associated with mature defenses ( $r_{\mathrm{s}}=0.89$, see Table 2 ). DOC was positively correlated with the mean depression score $\left(r_{\mathrm{s}}=0.84\right.$, see Table 2), and mature defenses were positively related to positive emotions $\left(r_{s}-0.89\right.$, see Table 2$)$.

\section{Discussion}

The purpose of this study was to investigate the time-courses and the relationships berween coping, defense mechanisns, enotions and depression considered as key factors in adaptation to ICE. During the 105 days of isolation and confinement, only emotion slyowed a sigrificant variation. A significant recrease in positive emotion was found for all the participaprs rhroughour the experiment, indicating that ICE environments might induce some changes in psychological states. Furthermore, relations between coping and boch defense and depression were noted. Coping strategies on the task-oriented dimension were associated with mature defense, which was also associated with positive emotion. Coping seraregies on the disengagement-oriented dimension were linked to symptoms of depression. These findings slow the impact of a space simulation on affective states, and the relations of defense to both coping and emotion, underlining the role of defense in psychologica! adaptation processes.

\subsection{Time-course in coping, emotion, defense mechanisnis and depression over time}

Longitudinal anatyses revealed that the average of the positive emotions varied significantly across the phases for all the participants throughout the experiment. Positive emotion showed a

Table 1

Mears and stand ald deviations (in parentheses) of coping, emotion, flefense mechanigms and deptession for each participant and group.

\begin{tabular}{|c|c|c|c|c|c|c|c|c|}
\hline Partielpants & TOC & DOC & $\begin{array}{l}\text { Mature } \\
\text { defenses }\end{array}$ & $\begin{array}{l}\text { Intermediate } \\
\text { delenses }\end{array}$ & $\begin{array}{l}\text { Immature } \\
\text { defenses }\end{array}$ & $\begin{array}{l}\text { Positive } \\
\text { cmotions }\end{array}$ & $\begin{array}{l}\text { Negative } \\
\text { Cmotions }\end{array}$ & $\begin{array}{l}\text { Depression } \\
\text { symptoms }\end{array}$ \\
\hline 1 & $5.33(1.12)$ & $0.79(3.18)$ & $3.94(0.25)$ & $1.63(0.22)$ & $1.94(0.35)$ & $3.30(0.29)$ & $1.06(0.01)$ & $0.03(0.06)$ \\
\hline 2 & $5.17(1.03)$ & $0.23(2.43)$ & $4.22(0.15)$ & $2.4(0.22)$ & $1.9(0.47)$ & $3.50(0.30)$ & $1.00(0.01)$ & $0,00\{0,00\}$ \\
\hline 3 & $3.16(0.8)$ & $0.30(1.55)$ & $3.5 \mathrm{~J}(0.14)$ & $2.81(0.30)$ & $2.4(0.33)$ & $2.68(0.33)$ & $1.16(0,07)$ & $0.00(0.01)$ \\
\hline 4 & $2,16(1,18)$ & $0.89(1.03)$ & $3.19(0.33)$ & $2 ; 48(0.30)$ & $2.25(0.42)$ & $2.95(0.25)$ & $1(0,0 t)$ & $0.01(0.01)$ \\
\hline 5 & $2.37(0.72)$ & $0.66(1.53)$ & $3.01(0.21)$ & $1.98(0.35)$ & $1.51(0.52)$ & $3.24(0.24)$ & $1.74(0.10)$ & $0,00(0,00)$ \\
\hline 6 & $3.76(0.5)$ & l. $14(1.78)$ & $4.18(0.19)$ & $2.25(0.17)$ & $1.64(0.67)$ & $3.49(0.29)$ & $1.11(0,05)$ & $0.04(0.06)$ \\
\hline Group & 3.66 $\{0.89\}$ & $0.67(1.92)$ & $3,68(0,21)$ & $2,26(0.25)$ & $1.94(0.46)$ & $3.26(0.23)$ & $1.07\{0.04\}$ & $0.01(0.02)$ \\
\hline
\end{tabular}

Notes; TOC: task-eriented coping; Doc: disengagement-oriented coping 


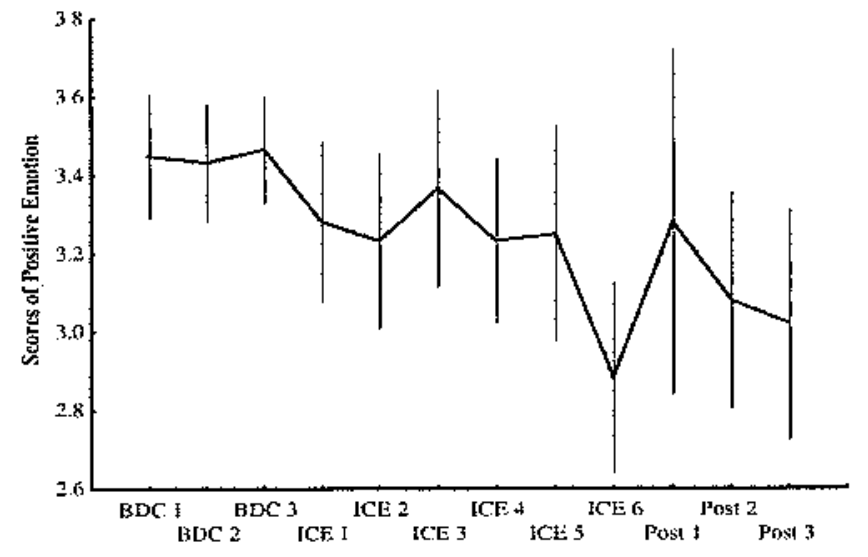

Fig. 1. Time-course of positive emotion theowhout the crperiment and during the different perods \{eg. BDC ICF and post\}

significant decrease between the three pertods of the experiment, before, during and after the ICE period. During the last days of the ICE (ICE 86 and ICE 99), a lower score of positive emotion was observed for all the participants. This suggests that the participants feit less enthusiastic, less active and less alert throughout the 105 day experiment and especially at the end of the ICE.

The findings of the present study support previous in vestigations, such as Peri's (1988) research on an italian Antarctic expedition, which showed that positive emotional states (tranquility, satisfaction, agreeableness) tend to decrease at the end. However, later psychometric studies cartied out on italiar expeditions during their Antarctic stay showed substantial enotional stability (Peri et al, 1998; Peri \& Tortora, 1989). This result is important becasse (1) a small decrease in positive emotions may perhaps represent the onset of tiredness, even exilaustion or sadness (Peri et al., 2000), and (2) numerous research studies on polar expeditions and wintering have identified emotional stability as being one of the most important factors of optimum performance and adaptation (Gunderson \& Kapfer, 1966; Palinkas et al. 2000; Sandal et al., 1996; Steel et al., 1997: Taylor, 1987).

The decrease in positive emotional states found in the present study and the previous psychonetric study seems to support the interpretation of a moderate but progressive reduction of emotional regulation (Peri et al., 2000). However, as mentioned in the introduction, Gunderson (1963) found that minot emotional disturbances were very common and cases of major emotional distubbance were extremely rare at Antarctic storions. The expressions of decrease in positive emotions among the marsonaurs increased in the final stages of the 105-dtay ICE environment, and the low scores on negative rroods suggest that overall the crewmembers' experience was not a negative and a major emotional disturbance.

Actually, given that the scores of positive emotion were higl at the beginning and that moods never reached the level of prominent and persistent manifestations of tension, anxiety or hostitity, the declease in positive emotions nilay have been induced by the critical period at the end of the experiment. in informal interviews after the experiment. the participants reported that the separation of the crew into two groups for the landing on Mars was experienced as breaking up the group, and it created a feeling of tiving in a vacuum for those who stayed in the principal motule. A possible explanation for this emotional variation could be the propensity for defensiveness or to deny the difficulties with a general enotional witlydrawal characterized by a self-distancing from positive feelings to protect oneself from possible frustrating events (Rivolier, Goldsmith, Lugg, \& Taylor, 1988). Thus, emotionalyy, the mar'sonauts tended to invest much less in what went on around them in order to protect themselves from the frustration and emotional deprivation that is often observed in ICE environments. 'This type of defense was qualified as a sort of frozer reactivity characterized by a low emotional response to the unwanted stimuli (Peri et al, 2000). All the findings collected up to now seent to support this type of emotional leveling (Barbarito, 1998) which is typical of personnel returning from an Antarctic campaign (Peri et al., 2000). For the present study, this interpretation was supported by informal interviews made in situ at the end of the experimentation with some of the marsonauts.

\subsection{Relations between coping, defense, emotion and depression}

As hypothesized, the findings showed significant relationships between coping strategies, emotional states, defense riechanistis and symptoms of depression. Significant positive correlations were found between mature defenses and both positive emotions and Task-Oriented Coping (TOC) and aiso between DisengagementOriented Coping (DOC) and symptoms of depression.

The associations between mature defenses and either positive emotions or JOC are in accordance with findings of previous studies conducted on adaptive situations such as recovery after surgery (Fulde et al. 1995), adjustment during adolescence (Erickson et al., 1997) or marital adjustment (Bouchard \& Thériasıltr, 2003). These results were confirmed in another constraining situation, sport competition (Nicolas \& Jebrane, 2008). Previous reseatch studtes led the authors to agree that the relationships berween coping strategies and dafense mechanisms in different constraining situations could indicate that they are both involved in psychological adaptation processes which concern not only coping strategies but also defense mechanisms. The simuttaneous investigation of coping strategies and defense mechanisms has proven to

Table 2

Correlations between coping, emotion, derense mechanisms and depression.

\begin{tabular}{|c|c|c|c|c|c|c|c|c|}
\hline & TOC & Dac & Mature slefensos & $\begin{array}{l}\text { Intermediate } \\
\text { dclenses }\end{array}$ & $\begin{array}{l}\text { Immature } \\
\text { defentes }\end{array}$ & $\begin{array}{l}\text { Posilive } \\
\text { enations }\end{array}$ & $\begin{array}{l}\text { Negative } \\
\text { emolions }\end{array}$ & $\begin{array}{l}\text { Depression } \\
\text { symptoms }\end{array}$ \\
\hline \multicolumn{9}{|l|}{$\mathrm{TOC}$} \\
\hline DOC & 0,20 & & & & & & & \\
\hline Int. D & 0.49 & 0.26 & -0.54 & & & & & \\
\hline $\mathrm{Im} . \mathrm{P}$ & 0.09 & $.0,14$ & -0.43 & 0.65 & & & & \\
\hline $\mathrm{PE}$ & 0.65 & -0.03 & 6.89: & 0.49 & .0 .60 & & & \\
\hline NE & 0.14 & 0.09 & -0.29 & 0,05 & 0.03 & -0.49 & & \\
\hline
\end{tabular}

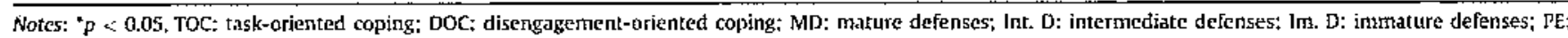
positive emotions, NE: negative emotions; DS: depression s.ymptoms. 
be the most fruitful path for studying ataptarion (Bouffard \& Crocker, 1992; Parker \& Endler, 1996), and may impiove uncerstanding of the complex and dynaric ways in which participants such as space flyers deal with the demands of constraining situations.

Furthermore, this study points out the relevance of measuring CS and DM at a patticular point in the training period in order to obtait a clearer and more valid psychological profite of the participants' psychological adaptation processes. Psyclsologists responding to the specific needs of individuals at a specific moment would then be able to intervene more effectively depending on the period of the mission. Finally, considering the often contradictory results, all attempts to accurately identify which type of $\mathrm{CS}$ is most effective in constraining situarions such as sport competitions have failed (Mnsluel \& Kaissidis, 1997). Consequently, during psychological preparation, psychologists shouid encourage participants to expand their coping straregy repeltoire to cope with the stress of the specific and evolving demands of different situations.

\subsection{Limils}

Because this longitudinal study was conducted in a ground-test spaçe simulation, there are certain intrinsic limitations that have to be mentioned. Inherent to these experimental conditions, the serious limitation of the present study is its small sample (6 men) whicl preciutes generalizations and deeper correlational analyses. in spite of previous research indicating divergent results including the appearance of negative emotions and symptoms of depression, other studies found no evidence for variations in psychological states and suggested that they are of little risk to the health and well-being of crew or to the success of the mission (Leon, McNally. \& Ben-Porath, 1989)

Several reasons could explatin the staisility of most of the psychological valiables: (1) Isolated and confined extreme environments are nor intrinsically stressful (Suedfeld \& Steel, 2000); stress is not inherent in ICE environment situations [Grigoriev \& Fedorov. 1996), or in other extreme situations such as simulated high altitude (Nicolas et al, 1999), or polar expeditions (Palinkas \& Suedfeld, 2007; Suedfeld, 1998). (2) The candidates were tested to ensure their capacity to stay and conclude this type of experiment. Therefore, the rigorous choice of the participants may atso explain the low variation in the psychological variables. The meticulous selection process involved here suggests that this population is highly motivated (Palirkas, 2003). Thus, the participants were more able to tolerate the trying conditions of isolation and confinement and to maintain high levels of performance over long periods of time (Paitikas 8 Browner. 1995).

The issue of the assessment method and the classic criticisms about self-report must also be raised. Future studies would benefit from the use of clinical assessment reports by externat observers instead of self-reports to assess psychologicat variables stzcl as CS and DM (e,g. Cramer, 1991). Finally, due to the Bonferroni correction, the lowet threshold was defined as the strict value of 0.0125 . It addition to tlye small rismber of participants and in spite of the high value of the Spearman correlation coefficient $\left(r_{s}\right)$ between several variables (see Table 2 ), the significant relationships between the different factors were difficult to reach.

\section{Conclusion}

The results of the present study offer additional insights into previous research on the effects of space simulation on psychological factors which are considered as essential in adaptation to ICE. They mainly suggest that ICE esvironments migbt induce some changes in psychological variables leading to subsequent alterations in aftective states. The nonlinear pattern of clange in emotion suggests that adaptation to prolonged isolation and confinement in an extreme environment might involve a significant decrease in positive emotion. This finding is important given that emotional stability is considered as a personality variable which can influetce the degree of adaptation in these specific contexts (Palinkas $\&$ Suedfeld, 2007). In addition. the relationships between enotion, coping and defense point out the interactive effect of JCE environments on psychological states and consequently a better understanding of the links between the parameters involved in psychological adaptation processes.

In a more integrative approach, our results confirmed previous research in different extreme situations which found that coping and defense are psychological constructs involved in psychological adaptation processes. Adaptation processes sluould be taken into account in orter to improve the selection and screening of space Iyers on the basis of psychosocial characteristics such as emotional stability and the development of coping strategies. In the perspective of space flights of long-duration sucl as the future missions to Mars, and given the limits presented above which require some caution regarding the generalization of the resuits, additional experiments are needed to further investigate the affective parameters of space flight-induced clianges. Further Feseatch would improve knowledge in order to offer participants a better selection, preparation and follow-up of these psychological components recognized as essential for adaptation to extreme environments.

\section{Acknowledgments}

Parts of this paper were presented at the MARS-500 congress at the Russian Acadenty of Sciences, April 23-25, 2012, Moscow, Federation of Russia.

The Mars-105 experiment was conducted at the Institute for Bio-Medical Problems (IBMP) in Moscow with the participation of the European Space Agency (ESA) and the Russian Space Agency (Roscosmos). We wish to thank all of the particjpants. the teams, the rescarchers and the collaborators who contributed to the success of this experiment. This study was supported by a research grant from the Centre Nationale d'Etudes 5patiales (CNES). France.

\section{References}

Atnericath Psychiatric Association. ( 1954), Diagnostic and statistical mantud of ntenfot disorders [4th ed, ]. Wastinglon, DC: American Psychiatric Association.

Andrews, G., Singh, M. B Bont, M. (1993). The klefense styte questionntire- foumal of Nerwous Mental Discases, 181, 246-256.

Anshel, M. H. \& Kaissidis, A. N. (1997). Coping style and situtional dppraisals t.5 predictors of coping sltategies following stress fitl events in spout as a lungtion of gender and skill level. British Jotrntal of Pyycholngy. 88, 263-275.

Barbarjlo, M. [1998). Cotrunicazione thersonale. Buenos Aircs: DNA-D.A.A

Beck, A., Steer, R., \& Brown, C. (1996), Beck depression inwen fory-ri, Mamad (2 ad ed.) San Artonio. TX: Psyctoological Corperation.

Bishop. I 5. [2004). Evaluating teams in extreme environments: From issues to answers, Aviation, Space, and Enwirommental Medicine, 75(7), C14-C21.

Bonsack,, ., Despland, J. N., : Spagnoti. . ( 1998 ). The French version of the defenge style questicnmaire. Psychotheropy and Pyctosomatics, 67, 24-30.

Bouchard, G. \& Therialul, V. J. (2003). Defense mechanisms and copigg strategies in conjugal relationships: $A n$ integration. mternational fournat of Psychology $38(2)$ $79-90$

Boullard, M., \& Crocker; P. (1992). Coping by individuals with physical disabilities with perceived challenge in plysical activity: Are they consistent? Resteurch Quarrerly for Exercise and 5port, $63,410-4 \mathrm{kt}$

Earver, C. S. (1997). You want to measure coping but prolocol's loo long: Consider the brief COl'E interational Joumal of Behavio we Medicine, $4(1), 82-100$.

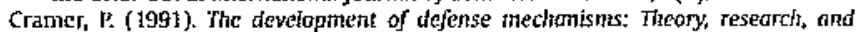
astessthent. New Yotk Springet-Vertag

Cramer, P. (1998). Coping and defense mechanisms: What's the dillerence? Jouthal of Persomality, 66, 919-946. 
Erickson, 5, Foldman, 5. 5. \& Steiber, F, (1997), Defense reactions and coping strategies in normal adolescents. Child Jsychibity and humban Development. $28[1], 45-56$.

Fulde, E., Junge, A., \& Alnrens, S. \{1995\}) Coping strategies and tefense mechanisms and theit retewance for the recovery after discectomy. fourtial of Psychosomatic Researcli, 39, 819-826

Grigoriev, A. l., \& Fedorov, B. M. (1996). Stress under nomal condilions, hypckinesi simulating weightlestress, and during hights in space. Vuman Physology, 22(2) $139-147$.

Grigoriev. A. I. Kozerenko. O. P. B Myasnikov. V. I. (1987). Selected problens of

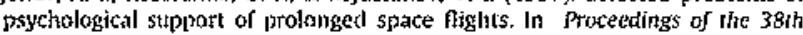
congress of the thtemational Astrong utical Fedaration. Stocklioln1, Sweden.

Gunderson, F. K. E. (1953). Finotional symptoms in extremeły isofatexl groups. Archives of General Psychiany, 9, 362-369.

Gunderson. E. K. E (1974) Psychological studies in Antarctica. in E. K. E. Gunderson (Ed.), Fumen doptobility to Antarcric conditions (pp. 115-131). Washington, DC: Mmericas Geophysical Ünion.

Ginderson, E. K. E.. \& Kapfer, E. L ( $196 \mathrm{G}$ ). The predictive validity of climical ratilza for all extreme envirenment, Britisir jourtal of Psychiohy. If2, 405-412

Gushin, V, l. (1995) l'Foblens of psychological control in prolonged space fights, Earti Space Revicw. 4. 28-31.

Islizakj, Y., Fukuoka, H., Katsurd, T. Nishimura, Y., Kiriyama, M., Higurashi, M. ct al. (1994). Psyclsological effects of bexl rest in youns healt lyy subjects. Acra thysiologta scandinarica Supplemetiriti, 616,83-37.

Ishizakt, Y., IshizakE, T., Fukuoka. H., Kim, C. S., Fujita, W., Maegawa, Y., et al (2002) Changes in mood status and nemrotic levels during a 20-day bed rest. Acto Astrotatrico, 50(7), 453-459.

Kanas, N. (1997). Psychosocial support for cosmonauts. Avation, 5pace, and Ettri ronmental Medicine, 62, 35,7-355.

Kanas, N, (1997). Fsychosocial value of space sinumation for extended spaceflight Adwances in Space Biology and Medicine, $6.81-91$.

Kanas, N. [2011], From earth's erbit to the ourer planets and berrond: Psychological issues in space. Acto Astronautica, 6r, 575-581.

Kanas. N., \& Manzey. D. (2008). Space psychotogy and psychiotry (2nd ed.). Fit Scgundo, CajicinialDordrecht: Microcosm Press/Springer/kltimer Acadenic Pres5.

Kanas, N. A., Salnitskiy, V. P. Ritsher. J. B., Gushin, V.I., Weiss, D.S., Saylor, S. A. et at [2006). Human interattions in space: ISS vs. Shuttle/Mit. Acta Astronatica, $5911) 413-419$

Leon, G. R., McN.1ly. C.. R. Ben-Porath, Y. (1989) P'etsonality characterislics. nood and coping parterns in a successfill Nortin Pote experition team. Jourdal of Reseorch in Personality, 23. I62-179

Manzey. D. (2004). Hujnan missions to Mars: New psychodogical challenges and reseatch issues. Acla Astrchautica, 55, 78 1-700

Manzey, D. \& Lorenz, B. ( 1997 ). Human performance during prolonged space flight.

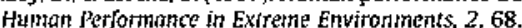

Myasnikov, V. I., R, Ramalettinow, I. 5. (1998). Psychological states and yroup in reractions of crewmembers in flight (Reprint). Huthan Perforntante in Extrem Environmats. 3. 44-56.

Nicolas, M., J Jebrane, A. (2008). Consjistency of coping serategies and deferse mechanisms durigg Iraining sessions and sport competitions. Imtemarionof Jotrmal of Sport Psythology, 39. 1-20.

Nicalss, M., \& Jebrate, A. (2008b). Rẹationships between coping strategies ant deferse mechanisms in sport perfomance. J'sychological Reports, 703, 735-74A

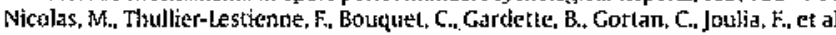
(196s). $4 n$ anxiety. personality and altitude symptomatology study in in dividuals partictpating in a 31 -day perioxl of hypokin in a hypobaric chamber

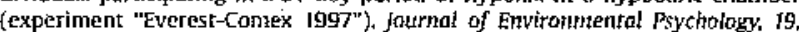
$407-414$

Nicolas, M. \& Weiss, K. (2009). Stress and recowery assessment during sinwlated mitrograwity: Elfects of exercise during a long-terfn head down tilt bed rest fin women. Joutulal of Emutrotitichtal Psyctologr, 29(4), 522-528.

Palinkas, L A. (1989). Sociocultum in fiences on pspeliosocial adjustment in Antarctica. Metical Arthropology, 10, 235-246.

Palinkas. I. A (200t). Psychosotial issues in long-tern space flight: Overvicw. Gravitotional arid Spoce Biology Bulletin, $\mathrm{J} 4[2]$

falinkas, A. A. (2003). The psychobsy of isolated and confined environments Amertican fsychologist 58, 353-363.

Palinkas, I. A., Brownet, D. (1995). Effects of prolonged isclation in extreme envirournents on stregs, coping. and depresston. jow mal of Applied Sacial frychology, 25, 557-576.
Falinkts, L. A. Gunderson. E. K. E., Holland, A. W., Miller, C., \& jołnson, J. C. (2000) Patedictors of bebaviot and perlonmance in extreme environments The An:arctic spice analogue program. Aviation, Space, and Enviroumenral Medicine, 71 arctie \$price.

Palinkas, L A, \& suedfeld, R. (2007). PSychological effects of polar expeditions, Tire Lancet, 365, 1-11.

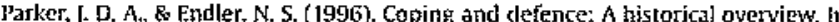
M. Zeidner, \& N. S. Endler (Eds.), Handbook of coping (pp. 3-23). New York Wilcy.

Peri, A. (1988). Questionatio di autovalutazione personale (OMP): Elabornztone validazione proliminare [The persothal sell assessment inventory: Elaboration and pzeliminary validation!. Anmalf di Aedicina Navale, 2, 231-24c.

['eri. A. Buffini, M. C. barattoni, M. Nisi, E, Scarlata, C. B Spera, E (1998), Le con-

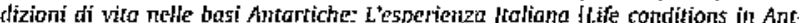
ortic stutions: The Ihafram experience] (Technical report no. 02,98), Rome: Itatian Antarctic Research Programme, Human Biology and Mediche Ated, ENEA, Progetio Antartide.

Peri, A, Scarlata, C., Barbarito, M, (2000) Preliminary stucties on the pswcluglogical adiustment in the Italian Antarcdic summer campaigns. Eftwfrotmment aro Beltevior, 32(1), 72-83.

Pet, A.. \& Torlora, A. \{ 1989\}). Wahutazioni psicometriche effettuate nel corso della II spedizione nazionale in Antaride [Psychometric monitoring of the 2nd Italian expedition to Antartical. Atthali di Medicina Navale, 4, 733-744.

Badloff, R. B Relmreich, R L (1968). Groups under stress - Ryychological reseorch in Serkb IL New York: Appleton-Century-Crofts.

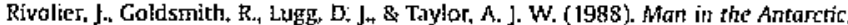
London: Taylor \& Francis.

Sandal, G. M., Bergan, T, Warıcike, M., Varmes, R., \& Ursin, H. (1996). I'sychological reactions during podar axpeditions and isolation in lyperbaric chambers. Space and Envirommental Medicine, 67, 227-234.

Sandal, G. M. Leon, G. R., \& Palinkas, l. A. (2006). Human claallenges in polar and space entronments. heviews in Environmental Science atd Bio/Technology 5 . $281-296$.

Skunmer, E. A., Lidge, K., Altman, J. \& Sherwood, H. (2003). Searching For the structure of coping: A review and critique of coregory systems for classifyilug ways of coping. Hychological Enillerin, 129, 216-269.

Steet, G. D., Stuedfeldi, P. Peri, A., \& Patenkas, L. A. (1997). People in higl latitudes: The "Hig Five" personality characteristics of the circunupolar sojourthet. Erwirommental Befouvior, 29, 324-347.

Steer. $R$. $A$ kissmiller. D. I.. \& Beck, A. T. (2000). Use or the Beck depression inventory-ll with depressed geriatric inpatients. Behaviow ficserd and Therapy. $38,311-318$

Sryf., ]. R., Huttchinsen, K., Carlsson, S. G., \& Hargens, A. R, (2D01). Depression, mood state, and batk pain during microgravity simulater by bed rest. Psychosonatic Medictite, 63, 862-864

Suedfeld $P$. (1991). Groups in isolation and confinement: Ënviconments and experiences. In A, A. Fatrison, Y. A. Glearwater. \& C. P. Mckay (Eds), Frotn Aldarctico to outer spoce. New York: Springer.

Suedreld, P. (1998). What can abnormal enwironments tell us about rormal people? Polar skations as natural psychology laborarartes. Journol of Emrironniental Psycitalogy, 18, 95-102.

Suedfeld, P. (2005). Invulnerability. coping, salutogenesis, inlegration: Four phases of space psychology. Aviation, Space, and Enwirommental Mediefme, 76. B61-866.

5ugdfefd, P., Brcic, ]. \& Legkaia, K. (2009) Coping with the problems of space flight; Reports from astronatul's ancl cosmonauts. Acto Astronoutica, 65, 312-324.

Suedfeld, P. B Steel, G. (2600). The environmental psychology of capsule habirats. Atrmital Rewiew of Psychology, 51, 227-253.

Taybr, A. J. W. (1987). Antarctic psychology. Wellington: Science Information Pilitishing Center, DSIR.

watson, D., B Clask, L (1997). 'the measurement and mismeasurentent of mood: Recurent ant emergent issucs. Jounal of Persongliy Mssessment, 86. 267-296.

Watson, D. Clatk L, \& Tellegen, A (1988), Developrent and validation of brief metasturas of positive and nezalive allect: The PANAS scales, journol of Persor-

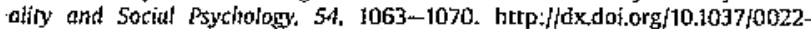
3514.54 .6 .1063

Wiltams, R. S., \& Davis. 1. R. (2005) A critical strategy: Enstruring behavioral health duting extended-duration space missians. Aviation Space and Erwtranmental Medicite. 7G[6 Suppi.), B1-B2

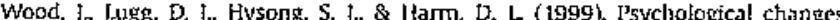
in hundred-day remore Murrictic field sroups. Enwitonnentol Behavior. 31, $299-337$. 